\title{
READER ENGAGEMENT IN L1 AND L2 SPEAKERS OF ENGLISH
}

\author{
Andriana Sabov \\ Student, Taras Shevchenko National University of Kyiv, Ukraine \\ e-mail: andriana.sabov@gmail.com,orcid.org/0000-0002-4860-9814
}

\begin{abstract}
Lidia Verba
Ph.D., Professor at the Department of the English Language and International

Communication, Taras Shevchenko National University of Kyiv, Ukraine e-mail: lidia.verba@gmail.com,orcid.org/0000-0003-3010-5746
\end{abstract}

\section{Summary}

The paper explores the use of metadiscourse markers by L1 speakers of English and proficient L2 speakers in opinion articles. The data for the analysis consists of 90 articles from the most popular newspapers in the USA, the UK and Ukraine, each variety represented with 30 articles. The classification of metadiscourse is primarily based on Hyland's taxonomy with a more detailed approach to identifying metadiscoursive occurrences. In addition to investigating the most common patterns of engagement across three varieties of English, the study looks into how those patterns influence L1 and L2 readers, in particularly how engaged they are in the reading process and they would rate the persuasiveness of the text. Findings suggest that despite all three varieties having approximately the same number of metadiscourse markers, there's a difference as to what types are prevalent in the variety. There are also differences observed concerning the reader engagement among L1 and L2 readers.

Keywords: metadiscourse markers, speakers of English, L1, L2, speakers of Ukrainian, school system in Ukraine.

DOI: https://doi.org/10.23856/4709

\section{Introduction}

Investigations into reader engagement have been conducted in the genres of research articles (Shen \& Tao, 2021), PhD these (Deng et al., 2021), institutional discourse writing (Aerts \& Yan, 2017) and many other types of texts. All of them have in common the fact that they look at metadiscourse as one of the major ways for writers to engage with readers.

Similarly, the researchhas been done on the difference in L1 and L2 speaking (Resnik, 2017) and writing (Bax et al., 2019), primarily in the academic setting. However, to date no inquiry has been done as to the use of metadiscourse by proficient L2 English writers with Ukrainian as their L1 in in opinion articles. Opinion article is a peculiar newspaper genre that is very audience-focused.

The paper aims at exploring the use of metadiscourse markers in the English writing of Ukrainian speakers in comparison with the use of such markers in British and American varieties in opinion articles. Those peculiarities are investigated not only in terms of production but also in terms of perception, text persuasiveness and reader engagement.

Such analysis aims at the comprehensive understanding of the writing strategies of the L2 writers and the perception of such writing by native speakers and vice versa. To achieve the aim, the following research questions were asked: 
- What are the most common types of metadiscourse markers in different varieties?

- Does the higher frequency of metadiscourse markers influence the text persuasiveness and reader engagement?

- Is there a difference in the text persuasiveness and reader engagement in L1 and L2 writing?

In the following sections we'll take a closer look at the methodology, data and the results that answer those questions. The findings will be discussed and possible explanations will be suggested.

\section{Background}

\subsection{Metadiscourse Markers}

The investigation into metadiscourse stems from Halliday's (Halliday \& Matthiessen, 2013) classification of three metafunctions of the language. Based on this, the further work was done by Vande Kopple (1985), Mauranen (1993), Ädel (2006), Hyland(2018) and others.

Studies of metadiscourse have been conducted in various fields and modalities. Qin \& Uccelli(2019) look into metadiscourse across different communicative contexts, Penz \& Marko(2017) investigate metadiscourse in interactions and McKeown \& Ladegaard(2020) in moderated group discussions, while Hyland \&Fu (2014) conduct a comparative analysis of popular science texts and opinion pieces.

The study of academic texts is a popular strand in the metadiscourse research. Investigations have been conducted on the use of metadiscourse markers in scientific writing across various disciplines (Hyland \& Jiang, 2018), in $\mathrm{PhD}$ candidature confirmation reports (Jiang \& Ma, 2018) and in book review articles (Birhan, 2021). Another common strand in metadiscourse research is investigation into the use of metadiscourse among different cultural groups. One of such studies have been done by Jokic(2017) who looked into the metadiscourse in speech of participants from various national backgrounds.by Resnik (2017),Molino (2018) and Farahani \& Sbetifard (2017)investigated the use of metadiscourse markers in English byL1 speakers of German, Mandarin Chinese. Italian and Iranian.There are also studies in diachronic linguistics that explore the use of metadiscourse e.g.Keramati et al. (2019).

Concerning the Ukrainian language, the only study that is somewhat similar to the study of metadiscourse and its cultural significance was conducted by Yakhontova (2006) where she explores the differences in academic writing in Ukrainian and English research articles.

The main problems concerning metadiscourse arise from the fact that the term itself is quite fuzzy. The primary difficulty lies in distinguishing metadiscourse from the propositional content. That is why a lot of studies look into metadiscourse as a device used to comment on the language in the text or as a way for the authors to express their stance ( $\ddot{d} d e l, 2006 ;$ Can \& Yuvayapan, 2018; Hyland, 2017).

Within metadiscourse studies two approaches can be identified (Ädel \& Mauranen, 2010)_ a narrow approach and a broad approach. Conversely, Hyland (2017) views this divergence as a continuum, where the narrow and broad approaches are at the opposite sides of the spectrum.

The broad approach usually presupposes retrieving tokens that may potentially have metadiscoursive function (like searching for personal pronouns). Then researchers analyze every occurrence in the corpus, excluding instances that are not metadiscoursive. Finally, the conclusions are drawn by investigating the most common patterns on the lexical and grammatical levels, or by classifying the functions performed by metadiscourse. Hyland's taxonomy (2018) is the most common within this approach and thus it was used in my research. The following table illustrates Hyland's classification: 
Hyland's taxonomy

\begin{tabular}{|c|c|}
\hline Category & Examples \\
\hline Interactive & in addition; but; thus \\
\hline Transitions & finally; to conclude \\
\hline Frame markers & noted above; in section 2 \\
\hline Endophoric markers & according to ...; ... states \\
\hline Evidentials & namely; e.g.; such as \\
\hline Code glosses & might; perhaps \\
\hline Interactional & in fact; definitely \\
\hline Hedges & unfortunately; surprisingly \\
\hline Boosters & I; we; my \\
\hline Attitude markers & consider; note \\
\hline Self-mentions & \\
\hline Engagement markers &
\end{tabular}

\subsection{Persuasion and Engagement in Opinion Articles}

The research into the opinion discourse in the media primarily focuses on the specificity of editorials, often considering those and the comment article to be of the same genre (Biber, 1988). However, there are researchers who disagree with that view on the grounds of editorials being more institutional (Van Dijk, 1988) and more impersonal(Murphy, 2005). Opinion articles, vice versa, provide the reader with a reliable "voice" (Shen \& Tao, 2021), allowing readers to evaluate and critically engage in texts aimed at persuading them. Virtanen (2005) further states that those genres differ in terms of their communicative purposes, the intended audiences, the writers' personalities, and the prototypical structure of the texts.

Opinion articles are also particular in that way that from the very beginning the author adopts the stance and then by different means they attempt to persuade the reader of that opinion (Fu\& Hyland, 2014). In research in this area it is generally agreed that certain linguistic structures or patterns can elicit reader engagement in the written discourse (Zhang, 2019). A number of studies has employed the research into metadiscourse as a tool of attaining persuasion in newspaper texts(Dafouz-Milne, 2008; Kashiha \& Marandi, 2019; Shahid et al., 2021).

\section{Data and Methods}

\subsection{Data}

The data for analysis consists of the corpus of 75 thousand words. Each subcorpus British, American and Ukrainian has 25 thousand words. Each subcorpus is balanced in terms of the wordcount and the topics covered. Additionally, I normalized the data to present the results in the word frequency of the words per thousand.

For each subcorpus I have chosen articles from the three popular online newspapers of each country. Therefore, the data in British subcorpus consists from the articles of The Telegraph, The Guardian and The Independent; the data for the American subcorpus was taken from The Washington Post, The New York Times and USA Today; the Ukrainian subcorpus consists of the articles from Unian, Business Ukraine and KyivPost. All of the articles are written in English. To ensure that there is consistency in the thematic orientation of the articles, I chose the articles that covered the following topics: International Affairs, Covid, Internal Problems, Culture and Economy. 


\subsection{Methods}

Since the paper focuses on the two aspects of metadiscourse markers use, the two distinct methodologies were used to achieve the goals of the investigation.

\subsubsection{Exploring the Peculiarities of Metadiscourse Markers Use}

The classification of the metadiscourse markers that I found the most appropriate for my research is that of Hyland's. The categories proposed by him and also the methods of retrieval were deemed best to search across three different subcorpora and subsequently to derive adequate comparisons between the three varieties used in the investigation. However, with this amount of data I was still able to take a closer look at the individual occurrences of metadiscourse markers, allowing me to conduct a more nuanced evaluation of the role that the metadiscourse plays in the given text.

Even though the research in this area is quite substantial and there are non-exhaustive lists of the lexical items available, I decided to compile my own, considering the fact that to date no research was done comparing British, American and Ukrainian opinion articles. There are two main sources for the list of words that were searched for. First, I used already predefined sets of words and phrases largely based on Hyland. Second, just like Zhang (2016), I surveyed every $10^{\text {th }}$ article in the corpus for the metadiscourse markers and then included them in my search.

\subsubsection{Measuring Reader Engagement and Designing the Questionnaire}

The use of metadiscourse markers has been linked with the reader engagement and persuasion. To measure this, I decided to carry out a survey. The study of similar kind was conducted by Dafouz-Milne (2008) who explored the persuasive effect of metadiscourse, comparing English and Spanish editorials.

For the survey I chose four texts - two of them from the subcorpus of the native variety and the other two from the subcorpus of Ukrainian opinion articles. One of the texts from the native variety had a high occurrence of metadiscourse markers, another - low occurrence of metadiscourse markers. The texts from the non-native variety have been chosen according to the same principle.Considering the factor of topic, the only one that could appeal to both L1 and L2 audiences was Covid.

One of the issues that I encountered in designing the questionnaire is the size the of texts. Each text is approximately 700-800 words long. Presenting participants with four texts of such length would lead for skewed results for the last texts, that is why, I opted for creating three focus groups with each receiving different sets of text to rate in terms of engagement:

1. A text from a native variety with high frequency of metadiscourse occurrence (engH) and a text from a native variety with low frequency of metadiscourse occurrence (engL);

2. A text from a native variety with high frequency of metadiscourse occurrence (engH) and a text from a non-native variety with high frequency of metadiscourse occurrence (ukrH);

3. A text from a native variety with high frequency of metadiscourse occurrence (engH) and a text from a non-native variety with low frequency of metadiscourse occurrence(ukrL);

The respondents were asked to rate the text on a scale from 1 to 5 according to two parameters answering the following questions:

- How engaging the text is?

- How persuasive the text is?

The main goal of my questionnaire was to determine the persuasive effect of the opinion articles and whether it is indeed so dependent on the metadiscourse markers use as the previous researchers have claimed to be the case in academic discourse. Therefore, I added another 
question with the possibility of multiple choice so that readers can decide for themselves after reading both texts what were the main factors that influenced their decisions in rating the text.

The first three categories were based on the same categories that Dafouz-Milne used, that is rational appeal, credibility appeal and affective appeal:

- Logical appeal

- Emotional appeal

- Author's knowledge of the topic.

I added one more option that I was concerned might influence the engagement of the readers - The length of the text.

The questionnaire was disseminated through various WhatsApp chats and Facebook groups of my peers, so respondents' age is in range from approximately 20 to 26-27 years old. All of them are university students of various disciplines.

All in all, there were 12 respondents for each focus group, in each group 6 native speakers and 6 non-native speakers of English, their level of English was self-reported as proficient.

\section{Results}

\subsection{Metadiscourse Markers Use by L1 and L2 writers}

Generally, all the subcorpora have roughly the same amount of metadiscourse markers. The following table presents the results with data in the corpus normalized per 1000 words:

Table 2

Frequency of Metadiscourse Markers Use

\begin{tabular}{|c|c|c|c|}
\hline Category & UK & US & Ukr \\
\hline Interactive markers & 9,60 & 11,47 & 10,94 \\
\hline Interactional markers & 7,54 & 5,97 & 6,60 \\
\hline Total & 17,15 & 17,45 & 17,54 \\
\hline
\end{tabular}

The results show that both L1 and L2 writers employ the similar amount of metadiscourse markers. However, by taking a closer look we can observe that there are differences in the distribution within the categories.

Concerning the peculiarities of use of interactive metadiscourse markers, the biggest distinctions can be observed in the use of frame markers in Ukrainian variety $(0,39 ; 0,47$; 1,31 words per thousand in the British, American and Ukrainian varieties respectively) and evidentials in American variety $(1,52 ; 3,32 ; 1,63$ words per thousand in the British, American and Ukrainian varieties respectively). Figure 1 captures this peculiarity as well as other features of interactive metadiscourse markers in non-native and native varieties:

Interactional metadiscourse markers are the ones that directly inform the reader, refer to the reader or engage in any sort of interaction with them. The discrepancies in the use of interactional metadiscourse are presentedin Figure 2:

In the Discussion section I will present the trends that are observed, especially focusing on the outlying data that best characterizes the writing of the speakers of different varieties. 


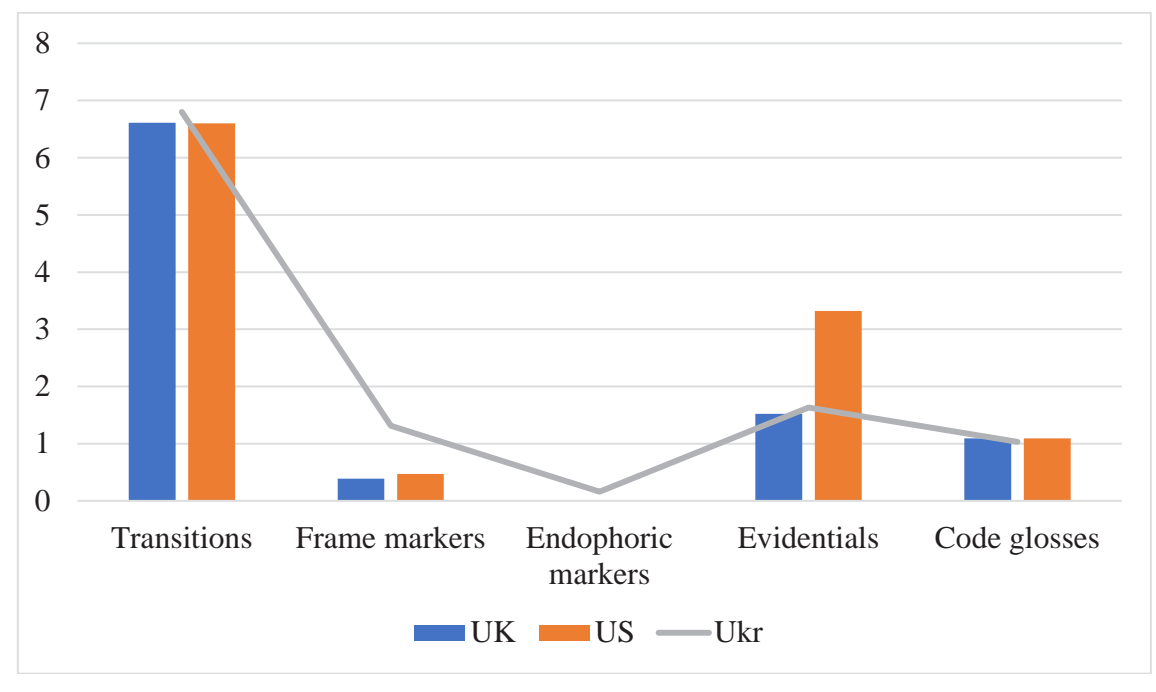

Figure 1. Interactive metadiscourse markers

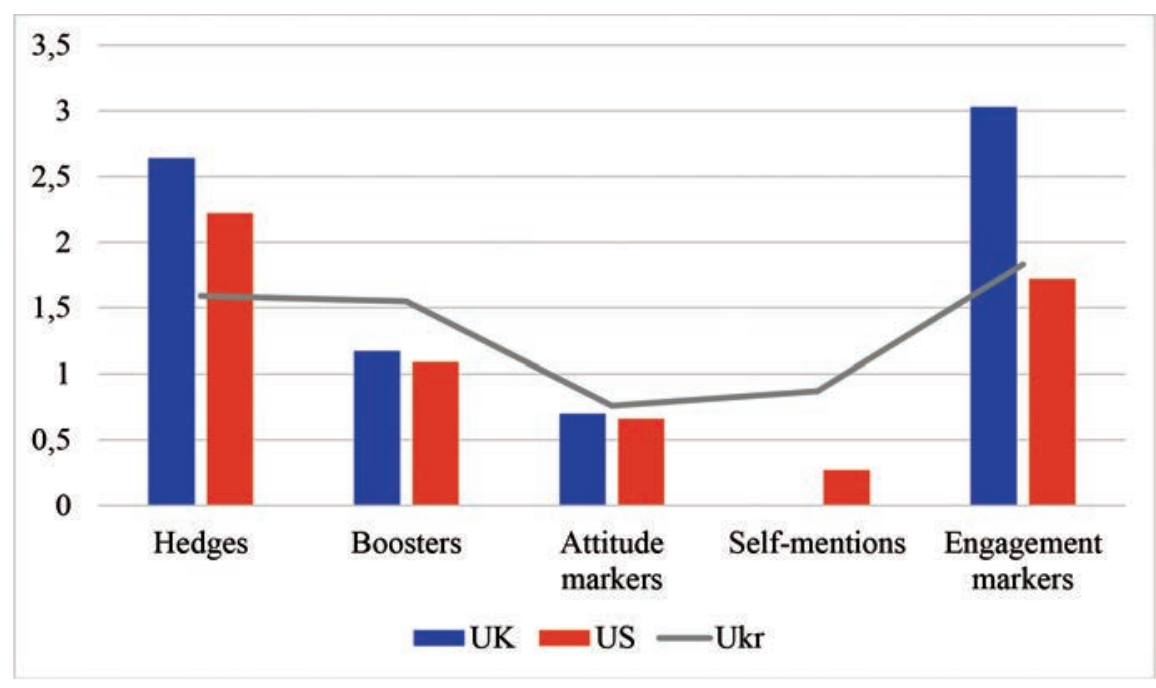

Figure 2. Interactional metadiscourse markers

\subsection{Reader Engagement and Text Persuasiveness in L1 and L2 Speakers}

Another aim of the paper is to see how features mentioned above might correlate in terms of engagement with target audiences.

Concerning the parameter of persuasion, the results don't differ much in terms of nationality and variety, except for one interesting thing. Native speakers rate the persuasiveness of texts native and non-native varieties generally to be 3 or 2 , while the persuasiveness of the non-native varieties is rated at 3 or 4 . Non-native speakers rate persuasiveness of the native 
text to be 4, while the persuasiveness of the non-native text is rated overwhelmingly to be 3 . The figure below shows the mean results of the rating:

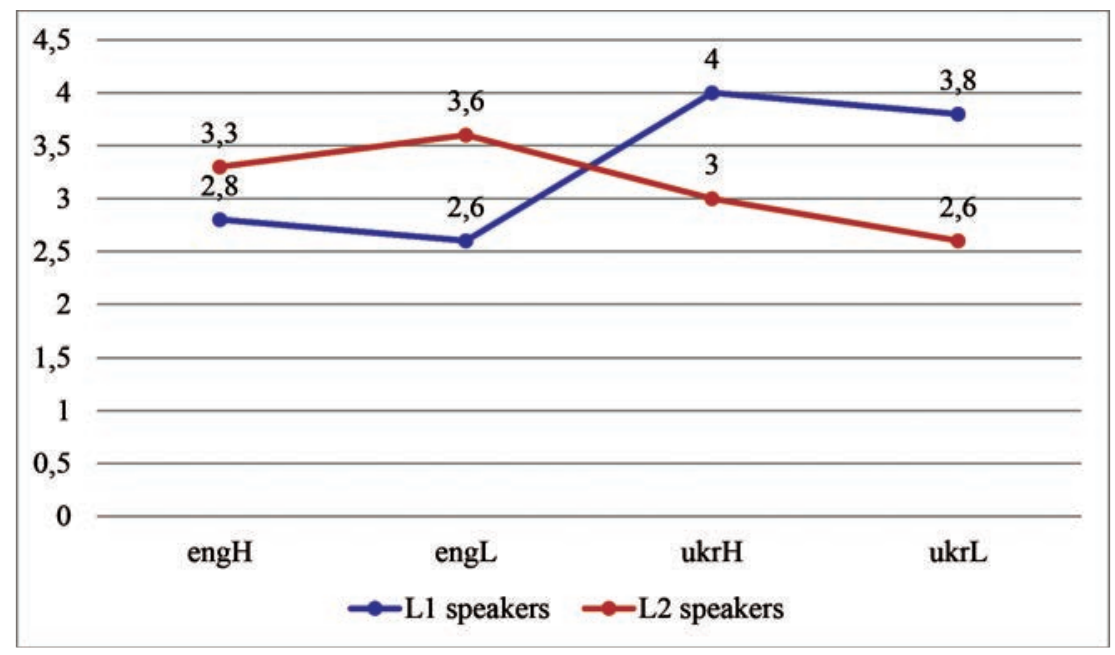

Figure 3. Reader Engagement as rated by L1 and L2 speakers

Judging from the obtained results, it appears that the use of metadiscourse markers had no effect on the persuasiveness of the text.

However, this is not the case with engagement, where there is clear evidence that the use of metadiscourse markers influenced the rating of the texts. The majority of the non-native speakers of English have rated the texts containing metadiscourse markers to be 4 or 5 on the scale of engagement, regardless of the variety. At the same time, the most common answer on the engagement scale for the texts with low frequency of metadiscourse markers occurrence from the non-native speakers was 3 . The following figure illustrates the trends obtained via questionnaire:

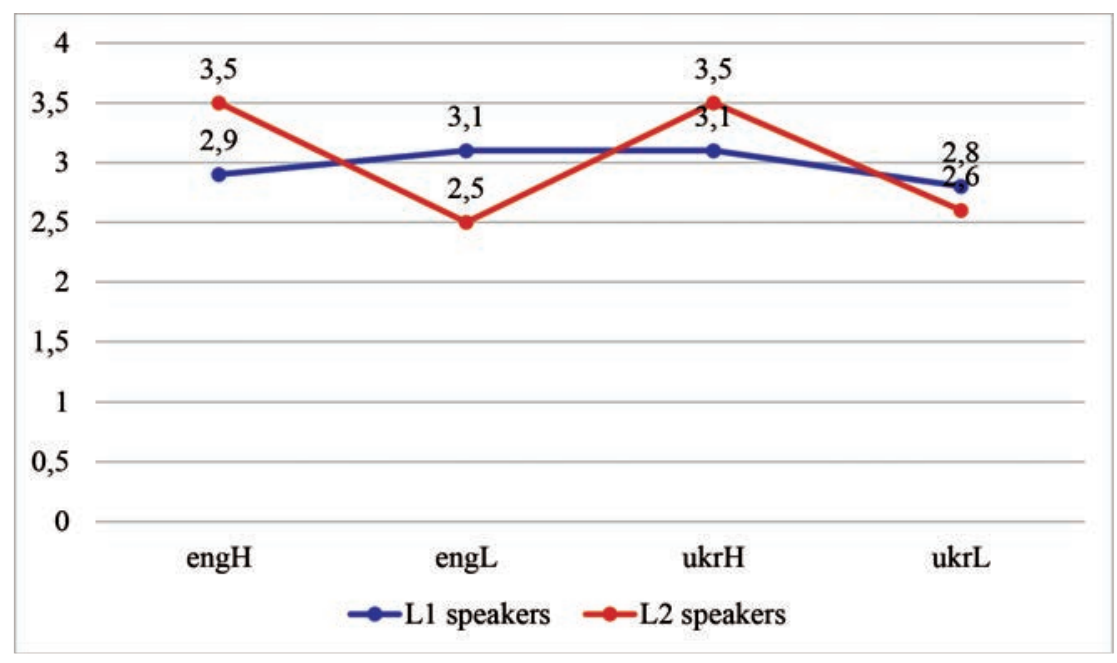

Figure 4. Text persuasiveness as rated byL1 and L2 speakers 
The interpretation of the results and possible implications of the study will be discussed in the following section.

\section{Discussion}

\subsection{The Use of Metadiscourse Markers}

Concerning interactive metadiscourse markers, transitions predictably are the most common among metadiscourse markers, and there is little difference between the frequency of use of this category.

One of the most vivid distinctions concerning the use of interactive metadiscourse markers is visible in the use of frame markers. According to the data obtained, in the Ukrainian variety the frequency of the frame markers usage is 1,31 words per thousand words, while British and American varieties show a frequency of use that is almost two times lower than that, i.e. 0,39 and 0,47 words per thousand words in British and American varieties respectively. Those irregularities in the use of frame markers in Ukrainian articles could be explained by the conventional demands of the classical opinion essay structure in Ukrainian tradition. The use of frame markers is taught throughout school and encouraged in universities. Frame markers are regarded as the primary means of cohesion between paragraphs. The findings suggest that contemporary Ukrainian opinion writers are strongly influenced by the essay writing tradition, especially when writing in their L2.

This inference can also be drawn from the fact that the Ukrainian variety is also the only one that employs endophoric markers. Though endophoric markers are not ample in the Ukrainian corpus, they are still present there (0,16 per thousand words), while the search for this type of metadiscourse markers did not yield any results in British and American corpora. The category of endophoric markers is commonly identified in the works investigating academic discourse (Ädel, 2017; Zhang \& Sheng, 2021) and students' writing (Bax et al., 2019; Yoon, 2021) while the previous research into the use of metadiscourse in newspaper genres also show low frequency of endophoric markers in opinion texts (Dafouz-Milne, 2008). Such low frequency of usage of endophoric markers in opinion articles in comparison to academic writing could be due to the specificity of the meaning that endophoric markers convey. This type of metadiscourse is used to relate the current argument to the information that was either mentioned before or, as in the case of research articles, to the previous findings in the field. That is why endophoric markers are quite prevalent in scientific writing. They facilitate the communication between the reader and the scientific text. Opinion articles are different in this regard. Authors of those texts don't refer as often to the previous or other opinions. Their goal in those text is to express their stance and provide a strong argument capable of convincing the reader of adopting that stance.

Another peculiarity of the endophoric markers is that they sound somewhat formal. British and American writers attempt to connect with the audience by using more neutral or colloquial phrases. Ukrainian writing tends to be more formal, more akin to the opinion essays or research articles, therefore it is no wonder that endophoric markers are sporadically present in the Ukrainian opinion articles.

One more type of interactive metadiscourse markers worth looking into is evidentials. Evidentials are the second most frequent interactive metadiscourse marker found in the corpora $(1,52 ; 3,32 ; 1,63$ words per thousand in the British, American and Ukrainian varieties respectively). They are used as a background to the opinion that the author presents or as supportive arguments to the author's claim. Interestingly, American writers employ twice as 
many evidentials than other analyzed varieties. This trend points to the fact that the authors of the American opinion articles tend to substantiate their claim with references to external sources. This trend has not been observed in British and Ukrainian opinion articles.

One of the first striking differences in the use of interactional metadiscourse markers appears to be the use of hedges. In native varieties authors show a high preference for this type of metadiscourse, while Ukrainian writing doesn't have such tendency. Hedges is one of those devices that demonstrate the author's commitment to the claim (Burrough-Boenisch, 2005). It is generally agreed upon that British English tends to be less direct in its expression. On the other hand, hedging as a phenomenon is not common in the Ukrainian language. Modal verbs play less significant role in the grammar system of the language, so adverbial modifiers are used as hedges in the expression of opinion. That could explain why Ukrainian authors use almost twice as less hedges as British authors.

The use of boosters is completely opposite to the use of hedges. Where native varieties show a high frequency of hedges, those same varieties use a lower number of boosters. Interestingly, Ukrainian variety is more or less balanced in terms of usage of those two metadiscourse categories. The main difference of boosters from all the other subtypes of metadiscourse is, as Hyland(2018)said, that they "allow writers to close down alternatives". This fact points to the peculiarity of the Ukrainian writing that instead of meandering around the point, the writers are more direct in the expression of their opinion.

Another feature in the use of boosters in a Ukrainian variety is that there are boosters that are present only in this variety. Interestingly, this is the only category of metadiscourse that has so many unique words. There could be two reasons for it. Firstly, the Ukrainian authors seem to use a lot of boosters in their native language and secondly, the Ukrainian language has a wide variety of lexical means to strengthen the proposition. Boosters that were found only in the Ukrainian opinion articles are inevitably, significantly, importantly, it is clear that.

Another interesting point I would like to make is that in Ukrainian opinion articles authors prefer to use clauses rather than sentence adverbials. For example, Clearly is never used as a booster in the Ukrainian subcorpus, it is usually substituted with It is clear that. On the contrary, Clearlyacts as an adverbial modifier, which is the exact opposite of the usage of the adverb in British and American varieties.

Even though the distribution of attitude markers is practically the same across the varieties, the Ukrainian subcorpus has a number of peculiarities that are worth mentioning. First, in Ukrainian opinion articles, the authors have a smaller number of unique attitude markers. By this I mean that the words that are quite commonly used in British and American varieties are absent in Ukrainian subcorpus. Such words as true, know,regretwere not found. Second, Ukrainian authors prefer to use either passive or impersonal construction. This was observed concerning other types of metadiscourse, so having encountered this phenomenon so many times I believe that this is a typical pattern for Ukrainian writing.

The category of self-mentions is perhaps the most interesting and the most complex to investigate. This category of metadiscourse is best identified when searching for personal pronouns and their oblique forms, as for example, $I$, me, we, our etc.Opinion articles are replete with those kinds of pronouns, however, the main problem in this case is separating metadiscursive $I$ from $I$ used in the propositional content. British English usually uses metadiscursive selfreference with attitude markers though those instances are comparatively rare. In the majority of cases, self-mentions are a part of propositional content, employed in the narration of the author's personal experiences that serve as a background to the problem that they want to discuss. American English has few instances of self-mentions that perform metadiscursive 
function, while Ukrainian variety demonstrates the preference for using metadiscursive selfmentions (with a frequency of 0,87 words per thousand in comparison to American English variety that has a frequency of 0,27 words per thousand).

Concerning engagement markers, the only irregularity that can be observed is that British English uses almost twice as many engagement markers as American and Ukrainian varieties. Moreover, it shows greater variability. Despite the most common engagement marker being rhetorical question, British authors often address the reader directly using a number of such verbs as remember, hold on, note etc. These results suggest that opinion articles written for British audiences are more interactional and that they expect readers to involved in the text.

\subsection{Reader Engagement}

From the results of the questionnaire, it can be seen that the speakers of their own variety tend to rate the persuasiveness of the text to be lower than the persuasiveness of the variety that is not native to them. This could be due to the fact that the prevailing discourse in their country has been already established and promulgated by either social media or newspapers. The majority of people already have a clear stance on the issue of vaccination and thus the opinion articles would have little to no effect on them regarding changing their opinion on the issue. On the other hand, there is a small likelihood that the speakers of those varieties were exposed to the narratives common in the articles in the other countries, especially Ukraine. Thus, this could be the reason why native speakers of English rated Ukrainian articles to higher on the scale of persuasiveness - they were genuinely interested in the discourse as it was something different from what they usually hear every day.

The same logic could be applied to the Ukrainian speakers. Generally, the Ukrainians are not particularly involved in British politics, and that's why, not knowing the prevailing narratives of the country, they considered the two texts that were presented to them to be convincing enough and rated them higher than the Ukrainian texts, the context of which is well known to them. Another factor that could have influenced their decision is the inherent bias in regarding native speakers of English as those who know better and write better. Even though I tried to minimize the influence of such bias by removing the name of the author and the source of the publication, the content of the articles might have given away which variety is the native one, and, for the majority of the Ukrainians per se stands higher in the hierarchy of credibility.

The situation is different however if we look at the parameter of engagement. Results show that metadiscourse markers are essential for the non-native speakers to orient themselves in the text, they boost their engagement in discourse and facilitate their understanding of the content.

For the native speakers, the use of metadiscourse markers appears not to make any big difference. All the texts, with and without metadiscourse markers of both native and non-native variety, were rated mostly 3 to 4 with no significant difference.

However, I still argue that metadiscourse markers have played a role in engaging the readers. When answering the question of what was the main factor that influenced their rating of the texts, the readers overwhelmingly chose the options "Author's word choices" and "Organization and structure". Even though the phrases seem a bit vague they still point to the use of metadiscourse markers, as those markers are the one that organize, structure and create the interaction between the author and the reader.

This conclusion is in line with the third most popular option for reasons for rating the text - "Logical appeal". This criterion demonstrates the author's ability to clearly and accurately present the information, make reader question and analyze the data. So far, the studies on metadiscourse have proven that metadiscourse markers play significant role in presenting that. 


\section{Conclusions}

In the paper the use of metadiscourse markers was explored in opinion articles by L1 and proficient L2 writers of English. Each of the varieties has their own peculiarities. Across the categories, the discrepancies in the usage of transitions, frame markers, evidentials, hedges and engagement markers stand out the most.

British English has an overwhelming number of Hedges and Engagement Markers. These findings are in keeping with the previous research in the field that has yielded similar results. American English uses a great number of Evidentials, which points to the fact that the authors of the American opinion articles tend to substantiate their claim with references to external sources.

The feature that stands out the most in the L 2 writing by Ukrainian authors is the greater adherence to the formal structures that is expressed through higher frequency of frame markers and endophoric markers in comparison to native varieties. Ukrainian writers also prefer to use metadiscourse in passive constructions which adds even more formality to the tone of opinion articles. Two possible explanations for the phenomenon could be the fact that authors write not in their native language and that they follow writing conventions typical for Ukrainian culture.

Concerning the engagement among L1 and L2 audiences, the results show that metadiscourse markers are essential for non-native speakers to orient themselves in the text, they boost their engagement in the discourse and facilitate their understanding of the content. Native speakers however, do not rely on metadiscourse that much. The results showed no significant discrepancy in the native speaker rating of engagement concerning the frequency of metadiscourse markers use in the articles.

The study offers a peak into the typical writing strategies among British, American and Ukrainian writers, and while it provides representative results, it is still limited by the choice of topics and source materials. By compiling a larger corpus and conducting a more rigorous investigation, other peculiarities may become apparent. In the study of engagement, further research in this area could implement eye-tracking to see how readers perceive texts with varying degrees of metadiscourse markers use.

As to the implementation of current research, the peculiarities of L2 writing can be tracked and improved in school system in Ukraine. The paper will also be of great interest to the researchers in pragmatics and manipulations in news discourse as the investigation touches upon factors that influence reader perception.

\section{References}

1. Ädel, A. (2006). Metadiscourse in L1 and L2 English / Annelie Ädel. Studies in Corpus Linguistics, 24, $x, 243 p$.

2. Adel, A. (2017). Remember that your reader cannot read your mind: Problem/solutionoriented metadiscourse in teacher feedback on student writing. English for Specific Purposes, 45, 54-68. https://doi.org/10.1016/J.ESP.2016.09.002

3. Adel, A., \& Mauranen, A. (2010). Metadiscourse: Diverse and Divided Perspectives. Nordic Journal of English Studies, 9(2), 1. https://doi.org/10.35360/njes.215

4. Aerts, $W$., \& Yan, B. (2017). Rhetorical impression management in the letter to shareholders and institutional setting: A metadiscourse perspective. Accounting, Auditing and Accountability Journal, 30(2), 404-432. https://doi.org/10.1108/AAAJ-01-2015-1916

5. Bax, S., Nakatsuhara, F., \& Waller, D. (2019). Researching L2 writers' use of metadiscourse markers at intermediate and advanced levels. System, 83, 79-95. https://doi.org/10.1016/j.system.2019.02.010 
6. Biber, D. (1988). Variation across Speech and Writing. Variation across Speech and Writing. https://doi.org/10.1017/CBO9780511621024

7. Birhan, A. T. (2021). An exploration of metadiscourse usage in book review articles across three academic disciplines: a contrastive analysis of corpus-based research approach. Scientometrics, 126(4), 2885-2902. https://doi.org/10.1007/S11192-020-03822-W

8. Burrough-Boenisch, J. (2005). NS and NNS scientists' amendments of Dutch scientific English and their impact on hedging. English for Specific Purposes, 24(1), 25-39. https://doi.org/10.1016/j.esp.2003.09.004

9. Can, C., \& Yuvayapan, F. (2018). Stance-Taking through Metadiscourse in Doctoral Dissertations. International Journal of Languages' Education, 6(1), 128-142. https://doi.org/10.18298/ijlet.2538

10. Dafouz-Milne, E. (2008). The pragmatic role of textual and interpersonal metadiscourse markers in the construction and attainment of persuasion: A cross-linguistic study of newspaper discourse. Journal of Pragmatics, 40(1), 95-113. https://doi.org/10.1016/j.pragma.2007.10.003 11. Deng, L., Fatemeh, B., \& Gao, X. (2021). Exploring the interactive and interactional metadiscourse in doctoral dissertation writing: a diachronic study. Scientometrics, 126(8), 7223-7250. https://doi.org/10.1007/s11192-021-04064-0

12. Farahani, M. V., \& Sbetifard, M. (2017). Metadiscourse Features in English News Writing among English Native and Iranian Writers: A Comparative Corpus-based Inquiry. Theory and Practice in Language Studies, 7(12), 1249-1261. https://doi.org/10.17507/TPLS.0712.12

13. Fu, X., \& Hyland, K. (2014). Interaction in two journalistic genres. English Text Construction, 7(1), 122-144. https://doi.org/10.1075/etc.7.1.05fu

14. Halliday, M. A. K., \& Matthiessen, C. M. I. M. (2013). Halliday's introduction to functional grammar: Fourth edition. In Halliday's Introduction to Functional Grammar: Fourth Edition. https://doi.org/10.4324/9780203431269

15. Hyland, K. (2017). Metadiscourse: What is it and where is it going? Journal of Pragmatics, 113, 16-29. https://doi.org/10.1016/j.pragma.2017.03.007

16. Hyland, K. (2018). Metadiscourse : Exploring Interaction in Writing. Bloomsbury Publishing Plc. http://ebookcentral.proquest.com/lib/uu/detail.action?docID $=5560196$

17. Hyland, K., \& Jiang, F. (Kevin). (2018). "In this paper we suggest”: Changing patterns of disciplinary metadiscourse. English for Specific Purposes (New York, N.Y.), 51, 18-30. https://doi.org/10.1016/j.esp.2018.02.001

18. Jiang, F., \& Ma, X. (2018). 'As we can see': Reader engagement in PhD candidature confirmation reports. Journal of English for Academic Purposes, 35, 1-15. https://doi.org/10.1016/j. jeap.2018.05.003

19. Jokic, N. (2017). Metadiscourse in ELF spoken discourse of Erasmus students in Austria. In Arbeiten aus Anglistik und Amerikanistik (Vol. 42, Issue 2, pp. 211-223). Narr Francke Attempto Verlag GmbH+Co. KG. http://uu.summon.serialssolutions.com/2.0.0/link/0/eLvHCXMwtV1LT9wwELYQJy6ohdJuecgnLiiVHOnsHDgss AhVuz3wuPQS2bEjRSkJ2mT P-PEye7CgfbQixWNLEfyNxp mcx8RoizHyR4ExMSokNDrRK5YiQhEbFUCm4Jy-I8o9q1Py $9-y-k v-X M-$ hZ2tNhLXtvwIPNoDeNdL-A_jjomCAZ3ABGMEJYPwrN1jYVrnO29oVa7jk

20. Kashiha, H., \& Marandi, S. (2019). Rhetoric-specific features of interactive metadiscourse in introduction moves: A case of discipline awareness. Southern African Linguistics and Applied Language Studies, 37(1), 1-14. https://doi.org/10.2989/16073614.2018.1548294

21. Keramati, S. R., Kuhi, D., \& Saeidi, M. (2019). Cross-Sectional Diachronic Corpus Analysis of Stance and Engagement Markers in Three Leading Journals of Applied Linguistics. Journal of Modern Research in English Language Studies, 6(2), 25-1. https://doi.org/10.30479/ JMRELS.2019.11293.1409

22. Kopple, W. J. Vande. (1985). Some Exploratory Discourse on Metadiscourse. College Composition and Communication, 36(1), 82. https://doi.org/10.2307/357609 
23. Mauranen, A. (1993). Contrastive ESP rhetoric: Metatext in Finnish-English economics texts. English for Specific Purposes, 12(1), 3-22. https://doi.org/10.1016/0889-4906(93)90024-I

24. McKeown, J., \& Ladegaard, H. J. (2020). Exploring dominance-linked reflexive metadiscourse in moderated group discussions. In Journal of pragmatics (Vol. 166, pp. 15-27). Elsevier B.V. https://doi.org/10.1016/j.pragma.2020.05.007

25. Molino, A. (2018). 'What I'm speaking is almost english... ”: A corpus-based study of metadiscourse in english-medium lectures at an Italian University.' Kuram ve Uygulamada Egitim Bilimleri, 18(4), 935-956. https://doi.org/10.12738/ESTP.2018.4.0330

26. Murphy, A. C. (2005). A corpus-based contrastive study of evaluation in English and Italian. 27. Penz, H., \& Marko, G. (2017). Metadiscourse in interactive contexts: An introduction . In Arbeiten aus Anglistik und Amerikanistik (Vol. 42, Issue 2, pp. 185-188). Narr Francke Attempto Verlag GmbH+Co. KG. http://uu.summon.serialssolutions.com/2.0.0/link/0/eLvHCXMwtV3PT9swFLaA0y7TBmODAcoFLlFQYrtxPIlDQPzQRtGkwWWXyj-lUpGiJuXAX7 n2GIDJ6Rx2CWy3DaK_LO-P39573sIEXycJis-QTvLsgSzgUixgrEkPLOGYcULwaSjJYe_ $i_{-}^{-}$ Km-D4szpd9DJdz_xV4mAPoXSHtG8Bf3BQm YAwmAFcwArj-kxkMTSNc5e3UJWs 4

28. Qin, W., \& Uccelli, P. (2019). Metadiscourse: Variation across communicative contexts. In Journal of pragmatics (Vol. 139, pp. 22-39). Elsevier B.V . https://doi.org/10.1016/j. pragma.2018.10.004

29. Resnik, P. (2017). Metadiscourse in spoken interaction in ESL: A multilingual perspective. In Arbeiten aus Anglistik und Amerikanistik (Vol. 42, Issue 2, pp. 189-210). Narr Francke Attempto Verlag GmbH+Co. KG . http://uu.summon.serialssolutions.com/2.0.0/link/0/eLvHCXMwtV1Ba9swFBalp13GurVrurbo1Evws GXJkgY9pCWljLSEJbnOYmzrBUyYU2rn -9JlhOnPXQ77GLMO8ig7_np09P7ngiJ2fcweBUT2FJrIwHpcY5OlAulBHDBinDJAJ3G1cs-qdGj-vmgxrvmFjvbfwUebQi9FdL-A jbQdGA7-gC-EQnwOdfucEDNJlV3q5tsYZN

30. Shahid, M. I., Qasim, H. M., \& Hasnain, M. (2021). Whites and Browns: A Contrastive Study of Metadiscourse in English Newspaper Editorials. Register Journal, 14(1), $25-42$. https://doi.org/10.18326/RGT.V14I1.25-42

31. Shen, Q., \& Tao, Y. (2021). Stance markers in English medical research articles and newspaper opinion columns: A comparative corpus-based study. PLoS ONE, 16(3 March), 1-22. https://doi.org/10.1371/journal.pone.0247981

32. Van Dijk, T. A. (1988). News as Discourse. Lawrence Erlbaum Associates.

33. Virtanen, T. (2005). "Polls and surveys show": Public opinion as a persuasive device in editorial discourse. In H. Halmari \& T. Virtanen (Eds.), Persuasion Across Genres : A linguistic approach (pp. 259-284). John Benjamins Publishing Company. http://ebookcentral.proquest. com/lib/uu/detail.action?docID $=622967$

34. Yakhontova, T. (2006). Cultural and disciplinary variation in academic discourse: The issue of influencing factors. Journal of English for Academic Purposes, 5(2), 153-167. https://doi.org/10.1016/j.jeap.2006.03.002

35. Yoon, H. J. (2021). Interactions in EFL argumentative writing: effects of topic, L1 background, and L2 proficiency on interactional metadiscourse. Reading and Writing, 34(3), 705-725. https://doi.org/10.1007/s11145-020-10085-7

36. Zhang, D., \& Sheng, D. (2021). EFL Lecturers' Metadiscourse in Chinese University MOOCs Across Course Types. Corpus Pragmatics : International Journal of Corpus Linguistics and Pragmatics, 5(2), 243-270. https://doi.org/10.1007/s41701-021-00098-0

37. Zhang, M. (2016). A multidimensional analysis of metadiscourse markers across written registers. Discourse Studies, 18(2), 204-222. https://doi.org/10.1177/1461445615623907

38. Zhang, M. (2019). Exploring Personal Metadiscourse Markers across Speech and Writing Using Cluster Analysis. Journal of Quantitative Linguistics, 26(4), 267-286. https://doi.org/10.1080/09296174.2018.1480856 